\title{
Prevalence of plant beneficial and human pathogenic bacteria isolated from salad vegetables in India
}

\author{
Angamuthu Nithya and Subramanian Babu*
}

\begin{abstract}
Background: The study aimed at enumerating, identifying and categorizing the endophytic cultivable bacterial community in selected salad vegetables (carrot, cucumber, tomato and onion). Vegetable samples were collected from markets of two vegetable hot spot growing areas, during two different crop harvest seasons. Crude and diluted vegetable extracts were plated and the population of endophytic bacteria was assessed based on morphologically distinguishable colonies. The bacterial isolates were identified by growth in selective media, biochemical tests and $16 \mathrm{~S}$ rRNA gene sequencing.

Results: The endophytic population was found to be comparably higher in cucumber and tomato in both of the sampling locations, whereas lower in carrot and onion. Bacterial isolates belonged to 5 classes covering 46 distinct species belonging to 19 genera. Human opportunistic pathogens were predominant in carrot and onion, whereas plant beneficial bacteria dominated in cucumber and tomato. Out of the 104 isolates, 16.25\% are human pathogens and $26.5 \%$ are human opportunistic pathogens.

Conclusions: Existence of a high population of plant beneficial bacteria was found to have suppressed the population of plant and human pathogens. There is a greater potential to study the native endophytic plant beneficial bacteria for developing them as biocontrol agents against human pathogens that are harboured by plants.
\end{abstract}

Keywords: Bacteriome, Endophyte, Human pathogenic, Plant beneficial, Salad, Vegetables

\section{Background}

Fresh vegetables are considered as the essential components of healthy diet of people and the consumption of vegetables in the form of salads has increased in many parts of the world, including India. In contrast to the potential health benefits of fresh vegetables, a concern about the safety and the quality of vegetables has also raised due to outbreaks of infectious diseases reported from by Center for Disease Control and Prevention (CDC), US Food and Drug Administration (FDA), World Health Organization (WHO) and Center for Science in the Public Interest (CSPI). These changes are mainly due to change in the ecology of human pathogens to persist in non-host environments.

\footnotetext{
* Correspondence: babu.s@vit.ac.in

School of Bio Sciences and Technology, VIT University, Vellore 632014, India
}

Since the contamination of salad vegetables with human pathogenic bacteria has reached concerning proportions in recent years, which has been evidenced by reports of various public health agencies through enhanced epidemiological and surveillance techniques, the raw vegetables are undoubtedly the portable source of infectious microorganisms, which has been revealed by numerous outbreaks associated with the consumption of salad vegetables $[1,2]$.

In general, fresh vegetables are known to harbour large bacterial populations [3], which may be of plant endophytes, plant pathogenic and human pathogenic in nature. The most important features of plant host colonization is by the adaptation of pathogens to the host defence response, physiology, immunity, native microflora, physical barriers, mobility and temperature. The pathogenic or non-pathogenic bacteria have several points of opportunities to contaminate fresh vegetables 
from the field through the time of consumption [4]. However, the route cause for the contamination of these vegetables, survival rate of endophytic bacterial communities, survival rate of pathogens which may be for plant or/and human, their interaction strategies, survival mechanisms are still under exploration.

Since the fresh vegetables in the form of salads are consumed raw, the pathogens present in it lead to widespread disease outbreaks. The non-pathogenic microbes associated with plants as a commensal or pathogen may leads to allergies which is still undeterminable due to change in the interaction strategies of microbes with the endophytic bacterial community and the plant host [5]. There are several reported outbreaks related to salad vegetables from the past decades to the present. Recently, Listeriosis outbreak was reported by CDC on January 28, 2016 from the consumption of mixed salad vegetables; E. coli 0157 outbreak was reported by USA Today newsletter related to salad vegetables in costco chicken; multistate Salmonella outbreak was linked to cucumbers in 2015 and thus the outbreaks are expanding.

In order to step on to the control of these outbreaks, detail reports of the endophytic bacterial community of vegetables used for salads, survival rate of pathogens in non-host environment etc. have to be identified. The present study was undertaken to find the endophytic bacterial community of the most commonly used South Indian salad vegetables like carrot, cucumber onion and tomato sold in vegetable markets. The study was undertaken by collecting the vegetable samples from two different vegetable growing hot spots of Tamil Nadu, India. Further, the endophytes were classified based on the evolutionary relationship to identify the predominant endophytic taxonomical group in salad vegetables and further classified based on their specific known functions such as human pathogens, human commensals, plant pathogens, plant commensals and environmentally beneficial bacteria.

\section{Methods}

\section{Sampling method and surface sanitization}

Fresh, damage-free whole salad vegetable samples (carrot, cucumber, onion and tomato) were purchased from two different local markets in Tamil Nadu, India (Hosur and Salem) during April and October of 2015. In Tamil Nadu, these two places are situated in the North Western agro climatic zone, but they differ in their soil type. The vegetable samples were collected in sterile plastic bags and transported to the laboratory as soon as possible. Samples were stored at $4{ }^{\circ} \mathrm{C}$ and tested within $48 \mathrm{~h}$. Carrot, cucumber and tomato samples were washed with sterile deionized water and the external surface was scrubbed with an alcoholic solution of iodine (2\%), and allowed to air dry inside a laminar airflow cabinet. The outer layer of onion was peeled and washed with deionized water and the external surface was scrubbed with an alcoholic solution of iodine (2\%). Sterilization efficacy was evaluated by cutting the scrubbed external surface with sterile scalpel blade and placing directly on the surface of nutrient agar medium. The method chosen for sterilization, treatment with alcoholic solution of $2 \%$ iodine and drying under UV light on each side of vegetables, proved to be effective in killing the surface associated bacteria. For every sample batch, two samples of each vegetable were randomly chosen following surface sterilization and placing the external surface on nutrient agar plate. After $24 \mathrm{~h}$ of incubation at $37{ }^{\circ} \mathrm{C}$, none of the tested vegetables showed bacterial growth.

\section{Endophytic bacteriological analysis of salad vegetables}

Twenty five grams of each salad vegetable sample was weighed aseptically and homogenized by blending in $225 \mathrm{~mL}$ of sterile buffered peptone water using commercial blender. One millilitre of each homogenate was mixed with $9 \mathrm{~mL}$ of sterile $1 \%$ buffered peptone water in a sterile test tube, labelled 1:10 $\left(10^{-1}\right)$ dilution and subsequent dilution was done in five other test tubes labelled $10^{-2}, 10^{-3}$ and $10^{-4}$. The same procedure was repeated for each sample and the blender was cleaned carefully and disinfected in between each samples to prevent cross contamination. For each vegetable, $100 \mu \mathrm{L}$ of undiluted (crude extract) and diluted $\left(10^{-2}, 10^{-3}, 10^{-4}\right)$ samples were plated separately on nutrient agar plates (HiMedia, Mumbai, India) by standard spread plate technique and incubated aerobically at $37{ }^{\circ} \mathrm{C}$ for $24 \mathrm{~h}$. All the discrete colonies were counted and expressed as colony forming units per gram $\left(\mathrm{CFU} \mathrm{\textrm {g } ^ { - 1 }}\right)$ of vegetable samples. Plating was done in three replications and the colony count was averaged.

\section{Isolation and biochemical characterization of endophytic bacteria}

Pure cultures were obtained by streaking isolated single colonies on nutrient agar plate by quadrant streak method and incubated at $37{ }^{\circ} \mathrm{C}$ for $24 \mathrm{~h}$. Colonies were presumptively distinguished based on the colony morphology on nutrient agar and selective media including AIA (Aeromonas Isolation Agar), CA (Certemaid Agar), EMBA (Eosin Methylene Blue Agar), MSA (Mannitol Salt Agar), SSA (Salmonella-Shigella Agar) and further tested for Gram's reaction, M (motility), I (Indole), MR (Methyl Red), VP (Voges - Proskauer), C (Citrate), C (Catalase), $\mathrm{O}$ (Oxidase) and $\mathrm{N}$ (Nitrate) and incubated at $37^{\circ} \mathrm{C}$ for $24 \mathrm{~h}$. 


\section{Isolation of DNA from endophytic bacteria}

Endophytic bacterial isolates from different salad vegetables were grown on nutrient agar plate and incubated overnight at $37{ }^{\circ} \mathrm{C}$. A single colony was suspended in a micro-centrifuge tube containing $30 \mu \mathrm{l}$ of sterile nuclease free water and heated at $94{ }^{\circ} \mathrm{C}$ for $10 \mathrm{~min}$. The sample was cooled to room temperature and centrifuged at $10,000 \mathrm{rpm}$ for $10 \mathrm{~min}$ and the supernatant was directly used as template DNA for PCR.

\section{Molecular identification of endophytes by 165 rRNA gene sequencing}

Partial sequencing of the 16S rRNA gene was done by PCR amplification of endophytic bacterial isolates using universal primers. SBBUF (5'-AGAGTTTGATCATGGC TCAG-3') and SBBUR (5'-TACGGCTACCTTGTTAC GAC-3') primers were used as forward and reverse primers, respectively. PCR amplification was carried out in a thermocycler (Eppendorf, Mastercycler, Hamburg, Germany). The reactions were routinely performed in $20 \mu \mathrm{l}: 2 \mu \mathrm{l}$ of $30 \mathrm{ng} / \mu \mathrm{l}$ endophytic bacterial DNA, $1 \mu \mathrm{l}$ of $0.5 \mu \mathrm{M}$ of each of the opposing amplification primers, $6 \mu \mathrm{l}$ of nuclease free water and $10 \mu \mathrm{l}$ of $1 \mathrm{X}$ PCR master mix (Ampliquon, Denmark) containing $1.5 \mathrm{mM} \mathrm{MgCl}_{2}$,Tris $\mathrm{HCl} \mathrm{pH} \mathrm{8.5,}\left(\mathrm{NH}_{4}\right)_{2} \mathrm{SO}_{4}, 0.2 \%$ Tween $20,0.4 \mathrm{mM}$ dNTPs, $0.2 \mathrm{U} / \mu \mathrm{l}$ Taq DNA polymerase, inert red dye and stabilizer. PCR amplification program for $16 \mathrm{~S}$ rRNA primers includes an initial denaturation of template DNA at $94{ }^{\circ} \mathrm{C}$ for $10 \mathrm{~min}$ followed by 30 cycles with a denaturation step at $94{ }^{\circ} \mathrm{C}$ for $1 \mathrm{~min}$, annealing at $49^{\circ} \mathrm{C}$ for $1 \mathrm{~min}$, and extension at $72{ }^{\circ} \mathrm{C}$ for $1 \mathrm{~min}$, and final extension at $72{ }^{\circ} \mathrm{C}$ for $7 \mathrm{~min}$. PCR amplified products were separated on $1 \%$ agarose gels containing ethidium bromide with molecular weight marker and visualized under a UV light. PCR products were purified and sequenced at Amnion Bioscience Pvt. Ltd. (Bengaluru, India) to determine the diversity and composition of the salad vegetables associated bacterial communities. Sequencing was performed with SBBUF and SBBUR primers using ABI 3730xl genetic analyser. The resulted nucleotide sequences were edited for any overlaps using Chromas Lite software.

\section{Sequence analysis and classification}

To ascertain the phylogenetic affiliation of the endophytic bacterial isolates, partial nucleotide sequences were assigned bacterial taxonomic affiliations based on the closest match to sequences available in the GenBank database (https://blast.ncbi.nlm.nih.gov/Blast.cgi) using the Basic Local Alignment Search Tool (BLAST) search algorithm. Sequence comparisons were done by constructing a sequence data matrix of $16 \mathrm{~S}$ rRNA genes of each endophytic bacterial isolate and further classified based on their nature of existence as human pathogen, human opportunistic pathogen, plant pathogen, plant beneficial, plant commensal and environmentally beneficial bacteria.

Phylogenetic trees were constructed based on neighbourjoining [6] and maximum-parsimony method using MEGA software, version 6 [7]. Bootstrap analyses were performed for 1000 replications. The nucleotide positions containing gaps and missed data were eliminated. The $16 \mathrm{~S}$ rRNA gene sequences determined in the study was deposited in the GenBank sequence library and their accession numbers are indicated on the tree.

\section{Diversity indices of endophytic bacteria}

The diversity indices of the endophytic bacterial isolates were calculated by using the PAST program version 2.10 [8].

\section{Results}

The results of this study provide insight into the identification of dominant members of the endophytic bacterial communities on the common South Indian salad vegetables such as carrot, cucumber onion and tomato.

The endophytic population was found to be comparably higher in cucumber and tomato in both of the sampling locations, whereas lower in carrot and onion (Fig. 1). The per gram fresh weight population density of endophytic bacterial isolates in carrot ranged from $5.4 \times$ $10^{-1}$ (crude extract) to $3.6 \times 10^{-4}\left(10^{-4}\right.$ dilution) CFU g ${ }^{-1}$, that of fresh cucumber ranged from $5.5 \times 10^{-1}$ (crude extract) to $4.2 \times 10^{-4} \mathrm{CFU} \mathrm{g}^{-1}\left(10^{-4}\right.$ dilution), fresh onion from $5.1 \times 10^{-1}$ (crude extract) to $3.4 \times 10^{-4} \mathrm{CFU} \mathrm{g}{ }^{-1}$ $\left(10^{-4}\right.$ dilution) and of fresh tomato from $5.5 \times 10^{-1}$ (crude extract) to $4.3 \times 10^{-4} \mathrm{CFU} \mathrm{g}^{-1}\left(10^{-4}\right.$ dilution). The reduction in population density by dilution of vegetable extract was more in onion compared to other vegetables. A total of 104 endophytic bacterial isolates were isolated from four vegetables based on their distinguishable colony morphology (shape, size, colour and margin). The total number of morphologically distinguishable isolates obtained from crude and diluted extracts of tomato collected in two seasons is 23 (Hosur - 16; Salem - 7), cucumber is 31 (Hosur - 21; Salem - 10), carrot is 30 (Hosur - 24; Salem - 6) and onion is 20 (Hosur - 14; Salem - 6). In the case of carrot collected from both locations and tomato from Salem, all the isolates are either from crude extract or $10^{-2}$ dilution. The isolates were designated as SBAN (authors name), followed by location of sample (H-Hosur; $\mathrm{S}$ - Salem), common name of vegetable (CA or $\mathrm{Ca}$ - carrot; $\mathrm{Cu}$ - cucumber; $\mathrm{O}$ onion; $\mathrm{T}$ - tomato) and the isolate number. Isolates obtained from crude extract and dilutions were numbered in sequential order. Since designation of some of the isolates were found to be overlapping after GenBank 


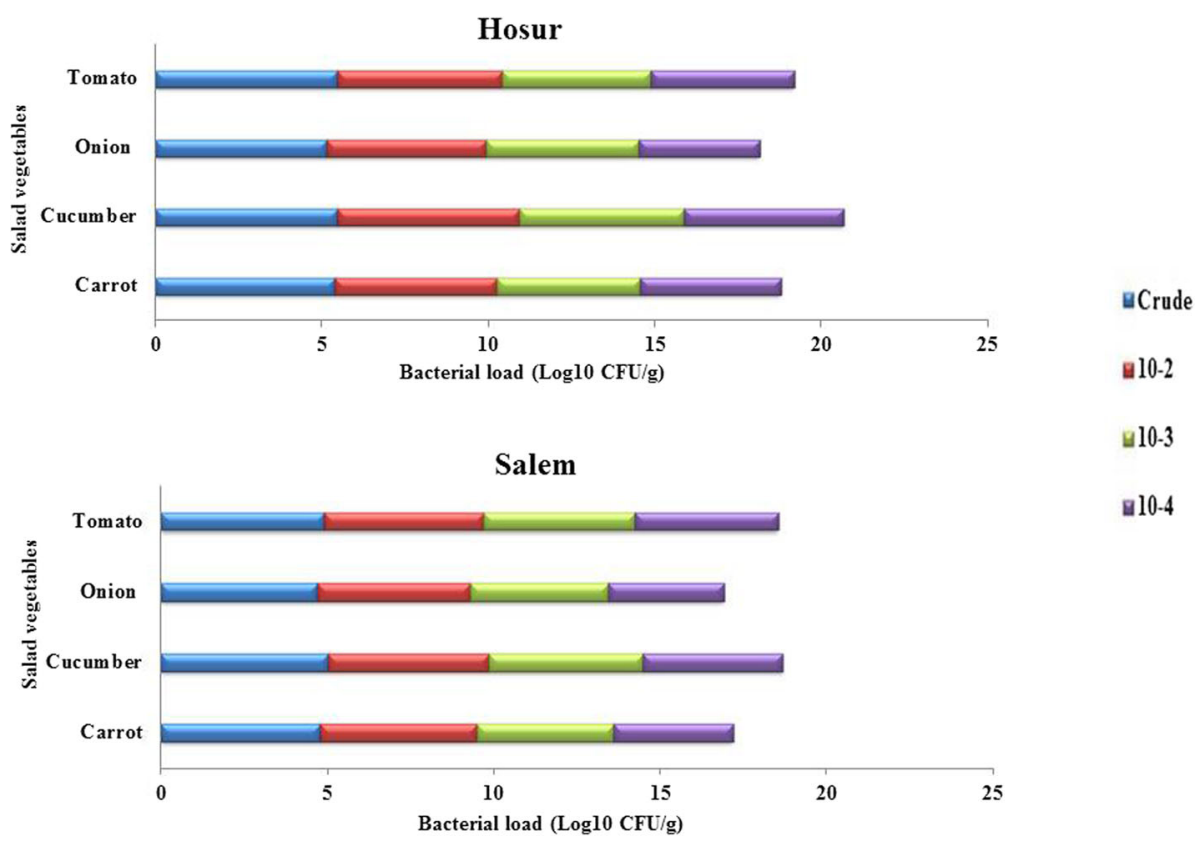

Fig. 1 Endophytic bacterial population from internal tissues of salad vegetables

submission, they were labelled as $1 \mathrm{a}, 2 \mathrm{a}$ etc for the purpose of differentiation.

The endophytic bacterial isolates were further characterized by observing their growth and colony morphology on selective media. On AIA media, only one isolate showed growth (SBANHCu11) and it was from Hosur cucumber. On CA media, the isolates SBANHCa1, SBANHCA14, SBANHCu19, SBANHCu20, SBANHCu22, SBANHCu25, SBANCu25a, SBANSCu19, SBANSCu20, SBANSCu22, SBANHO5, SBANHO8 and SBANHO14 exhibited yellowish-green to blue colonies, which represented the presence of Pseudomonas spp. EMB agar screening revealed no isolates with green-metallic sheen, which represents the absence of E. coli. SBANHCA2, SBANH Ca7a, SBANHCa10, SBANHCa11, SBANHCa14a, SBAN SCu7, SBANHO2, SBANHO15, SBANSO90, SBANHT7, SBANHT9, SBANHT14 and SBANHT15 isolates showed yellowish colonies in MSA media, which indicated the presence of Staphylococcus spp. and on SS agar medium the isolates SBANHCA3, SBANHCa4 and SBANHT11 showed black colour colonies, representing the presence of Salmonella spp.

Further, biochemical characterization of endophytic bacterial isolates was done in which, about $57.7 \%(n=60)$ of the isolates were identified as Gram positive and the remaining $42.3 \%(n=44)$ of the isolates as Gram negative. The existence of rod shaped endophytic bacterial population were about $87.5 \%(n=91)$ and the cocci were about $12.5 \%(n=13)$. In motility test, $79.8 \%(n=83)$ were found to be motile and $20.2 \%(n=21)$ were non-motile. The isolates were also classified based on I, MR, VP, C, catalase, oxidase and nitrate test, and the results are shown in Additional file 1: Table S1(a), (b), (c) and (d).

Molecular characterization of all the 104 endophytic bacterial isolates was carried out by PCR amplification of the genomic DNA using universal bacterial primers for $16 \mathrm{~S}$ rRNA gene. The expected size of $1.2 \mathrm{~kb}$ fragment for each of the 104 isolates was obtained and sequenced. The nucleotide sequences were searched for homology in the NCBI GenBank database using the BLASTn program. The results showed highest homology of $>97$ to 100 . Based on the 16S rRNA gene sequence identity, bacterial isolates were found belonging to 5 classes namely actinobacteria (11\%), bacilli (43\%), cocci (4\%), betaproteobacteria (3\%) and gammaproteobacteria (39\%) with 46 distinct species belonging to 19 genera. The data also indicated the existence of more diverse endophytic bacterial communities in tomato and cucumber in both the sampling locations as compared to onion and carrot. Among the various endophytic bacterial populations, the class bacilli was found to be predominant with 21 diverse genera followed by gammaproteobacteria (14 genera), actinobacteria ( 8 genera), betaproteobacteria (2 genera) and cocci (1 genera). Actinobacteria was found to be distributed high in cucumber compared to other salad vegetables. Distribution of bacilli was high in tomato, whereas cocci were predominantly present in carrot. Betaproteobacteria and gammaproteobacteria were high in cucumber.

The taxonomical classification of endophytic bacterial isolates of salad vegetables observed in the study is presented in Table 1 . Phylogenetic analysis was done by 
Table 1 Taxonomical classification of the bacterial isolates from salad vegetables

\begin{tabular}{|c|c|c|c|c|c|c|}
\hline Isolate ID & Phylum & Class & Order & Family & Genus & Species \\
\hline $\begin{array}{l}\text { SBANHCA1, } \\
\text { SBANHCa5, } \\
\text { SBANHCa6, } \\
\text { SBANHCa13, } \\
\text { SBANHO7 }\end{array}$ & Proteobacteria & Gammaproteobacteria & Xanthomonadales & Xanthomonadaceae & Stenotrophomonas & maltophilia \\
\hline $\begin{array}{l}\text { SBANHCA2, } \\
\text { SBANHCa10, } \\
\text { SBANHCa11, } \\
\text { SBANHO2 }\end{array}$ & Firmicutes & Coccus & Bacillales & Staphylococcaceae & Staphylococcus & aureus \\
\hline $\begin{array}{l}\text { SBANHCA3, } \\
\text { SBANHCa4, } \\
\text { SBANHT11 }\end{array}$ & Proteobacteria & Gammaproteobacteria & Enterobacteriales & Enterobacteriaceae & Salmonella & enterica \\
\hline $\begin{array}{l}\text { SBANHCA7, } \\
\text { SBANHCa9 }\end{array}$ & Proteobacteria & Gammaproteobacteria & Enterobacteriales & Enterobacteriaceae & Enterobacter & aerogenes \\
\hline SBANHCa8 & Proteobacteria & Betaproteobacteria & Burkholderiales & Alcaligenaceae & Bordetella & bronchiseptica \\
\hline $\begin{array}{l}\text { SBANHCa12, } \\
\text { SBANHCA15, } \\
\text { SBANHCA17, } \\
\text { SBANHCA15a, } \\
\text { SBANHCa17a, } \\
\text { SBANHO1, } \\
\text { SBANHO4, } \\
\text { SBANHO12, } \\
\text { SBANSO81, } \\
\text { SBANHT10, } \\
\text { SBANHT12, } \\
\text { SBANST3 }\end{array}$ & Firmicutes & Bacilli & Bacillales & Bacillaceae & Bacillus & pumilus \\
\hline $\begin{array}{l}\text { SBANHCA14, } \\
\text { SBANHCa1a }\end{array}$ & Proteobacteria & Gammaproteobacteria & Pseudomonadales & Pseudomonadaceae & Pseudomonas & aeruginosa \\
\hline SBANHCA16 & Firmicutes & Bacilli & Bacillales & Paenibacillaceae & Paenibacillus & polymyxa \\
\hline SBANHCa16a & Firmicutes & Bacilli & Bacillales & Paenibacillaceae & Paenibacillus & illinoisensis \\
\hline SBANHCa2a & Proteobacteria & Gammaproteobacteria & Enterobacteriales & Enterobacteriaceae & Enterobacter & hormaechei \\
\hline $\begin{array}{l}\text { SBANHCa7a, } \\
\text { SBANHT9, } \\
\text { SBANHT14, } \\
\text { SBANHT15 } \\
\text { SBANHCa14a }\end{array}$ & Firmicutes & Bacilli & Bacillales & Staphylococcaceae & Staphylococcus & sciuri \\
\hline SBANSCa3 & Firmicutes & Bacilli & Bacillales & Bacillaceae & Bacillus & aerophilus \\
\hline SBANSCa4 & Firmicutes & Bacilli & Bacillales & Bacillaceae & Bacillus & cereus \\
\hline SBANSCa5 & Actinobacteria & Actinobacteria & Actinomycetales & Microbacteriaceae & Microbacterium & oleivorans \\
\hline SBANSCa6 & Actinobacteria & Actinobacteria & Micrococcales & Micrococcaceae & Arthrobacter & nicotianae \\
\hline $\begin{array}{l}\text { SBANSCa7, } \\
\text { SBANHT4, } \\
\text { SBANST8, } \\
\text { SBANST12 }\end{array}$ & Firmicutes & Bacilli & Bacillales & Bacillaceae & Bacillus & subtilis \\
\hline $\begin{array}{l}\text { SBANSCa10, } \\
\text { SBANSO82, } \\
\text { SBANHT3 }\end{array}$ & Firmicutes & Bacilli & Bacillales & Bacillaceae & Bacillus & flexus \\
\hline $\begin{array}{l}\text { SBANHCu23a, } \\
\text { SBANHCu15, } \\
\text { SBANHCu23, } \\
\text { SBANHCu16, } \\
\text { SBANHCu17, } \\
\text { SBANHCu14a, } \\
\text { SBANHCu15a, } \\
\text { SBANHCu17a, } \\
\text { SBANHT1, } \\
\text { SBANHT16, } \\
\text { SBANHT17 }\end{array}$ & Proteobacteria & Gammaproteobacteria & Xanthomonadales & Xanthomonadaceae & Stenotrophomonas & rhizophila \\
\hline
\end{tabular}


Table 1 Taxonomical classification of the bacterial isolates from salad vegetables (Continued)

\begin{tabular}{|c|c|c|c|c|c|c|}
\hline SBANHCu24 & Actinobacteria & Actinobacteria & Micrococcales & Micrococcaceae & Arthrobacter & mysorens \\
\hline $\begin{array}{l}\text { SBANHCu25a, } \\
\text { SBANSCu19, } \\
\text { SBANHCu19, } \\
\text { SBANHCu22, } \\
\text { SBANSCu22, }\end{array}$ & Proteobacteria & Gammaproteobacteria & Pseudomonadales & Pseudomonadaceae & Pseudomonas & xanthomarina \\
\hline $\begin{array}{l}\text { SBANHCu10, } \\
\text { SBANHT21 }\end{array}$ & Actinobacteria & Actinobacteria & Micrococcales & Promicromonosporaceae & Cellulosimicrobium & cellulans \\
\hline SBANHCU12 & Actinobacteria & Actinobacteria & Micrococcales & Microbacteriaceae & Microbacterium & schleiferi \\
\hline SBANHCu14 & Proteobacteria & Gammaproteobacteria & Xanthomonadales & Xanthomonadaceae & Xanthomonas & axonopodis \\
\hline $\begin{array}{l}\text { SBANHCu20, } \\
\text { SBANHO3, } \\
\text { SBANHO5, } \\
\text { SBANHO8, } \\
\text { SBANHO13, } \\
\text { SBANHO14 }\end{array}$ & Proteobacteria & Gammaproteobacteria & Pseudomonadales & Pseudomonadaceae & Pseudomonas & stutzeri \\
\hline $\begin{array}{l}\text { SBANHCu21, } \\
\text { SBANSCu21 }\end{array}$ & Proteobacteria & Betaproteobacteria & Burkholderiales & Alcaligenaceae & Achromobacter & xylosoxidans \\
\hline SBANHCu24a & Actinobacteria & Actinobacteria & Micrococcales & Micrococcaceae & Arthrobacter & protophormiae \\
\hline SBANHCU25 & Proteobacteria & Gammaproteobacteria & Pseudomonadales & Pseudomonadaceae & Pseudomonas & indoloxydans \\
\hline SBANHCU11 & Proteobacteria & Gammaproteobacteria & Aeromonadales & Aeromonadaceae & Aeromonas & hydrophila \\
\hline SBANSCU4 & Firmicutes & Bacilli & Bacillales & Bacillaceae & Geobacillus & stearothermophilus \\
\hline SBANSCU7 & Firmicutes & Bacilli & Bacillales & Staphylococcaceae & Staphylococcus & haemolyticus \\
\hline SBANSCU8 & Firmicutes & Bacilli & Bacillales & Bacillaceae & Bacillus & aerius \\
\hline $\begin{array}{l}\text { SBANSCU9, } \\
\text { SBANSCu11, } \\
\text { SBANST7, } \\
\text { SBANST11 }\end{array}$ & Firmicutes & Bacilli & Bacillales & Bacillaceae & Bacillus & megaterium \\
\hline $\begin{array}{l}\text { SBANSCu10, } \\
\text { SBANHCu12a, } \\
\text { SBANSO80 }\end{array}$ & Actinobacteria & Actinobacteria & Micrococcales & Microbacteriaceae & Microbacterium & arborescens \\
\hline SBANSCU20 & Proteobacteria & Gammaproteobacteria & Pseudomonadales & Pseudomonadaceae & Pseudomonas & fluorescens \\
\hline SBANHO6 & Proteobacteria & Gammaproteobacteria & Xanthomonadales & Xanthomonadaceae & Xanthomonas & fuscans \\
\hline SBANHO9 & Firmicutes & Bacilli & Bacillales & Listeriaceae & Listeria & monocytogenes \\
\hline SBANHO11 & Firmicutes & Bacilli & Bacillales & Bacillaceae & Bacillus & anthracis \\
\hline SBANHO15 & Firmicutes & Bacilli & Bacillales & Staphylococcaceae & Staphylococcus & epidermidis \\
\hline $\begin{array}{l}\text { SBANSO90, } \\
\text { SBANHT7 }\end{array}$ & Firmicutes & Bacilli & Bacillales & Staphylococcaceae & Staphylococcus & gallinarum \\
\hline SBANSO54 & Firmicutes & Bacilli & Lactobacillales & Enterococcaceae & Enterococcus & faecium \\
\hline SBANSO83 & Firmicutes & Bacilli & Bacillales & Bacillaceae & Bacillus & aryabhattai \\
\hline SBANHT8 & Firmicutes & Bacilli & Bacillales & Bacillaceae & Geobacillus & stearothermophilus \\
\hline SBANHT13 & Firmicutes & Bacilli & Bacillales & Bacillaceae & Exiguobacterium & acetylicum \\
\hline SBANHT19 & Actinobacteria & Actinobacteria & Micrococcales & Microbacteriaceae & Microbacterium & testaceum \\
\hline SBANST6 & Firmicutes & Bacilli & Bacillales & Bacillaceae & Terribacillus & saccharophilus \\
\hline SBANST6a & Firmicutes & Bacilli & Bacillales & Bacillaceae & Bacillus & tequilensis \\
\hline
\end{tabular}

constructing the neighbour joining phylogenetic tree of all the 104 endophytic bacterial isolates to explore the evolutionary relationship, and the evolutionary distance was calculated using maximum composite likelihood method using MEGA software, version 6. Figure 2 represents the phylogenetic tree based on $16 \mathrm{~S}$ rRNA sequences of the isolated bacteria. The overall class distribution of bacterial isolates from all the four vegetables of both of the sampling locations is illustrated in Fig. 3. Sequences were deposited in the GenBank and the 


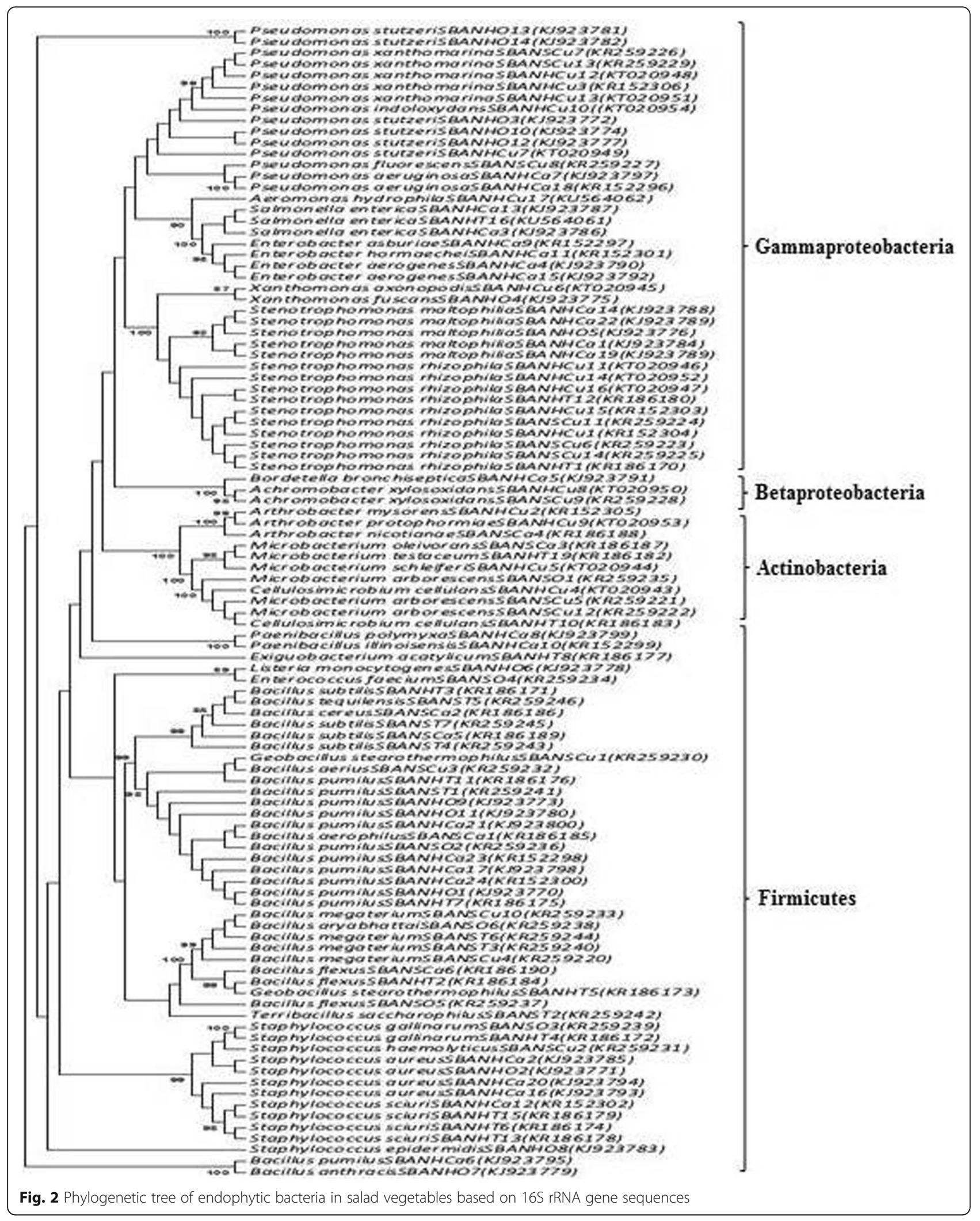




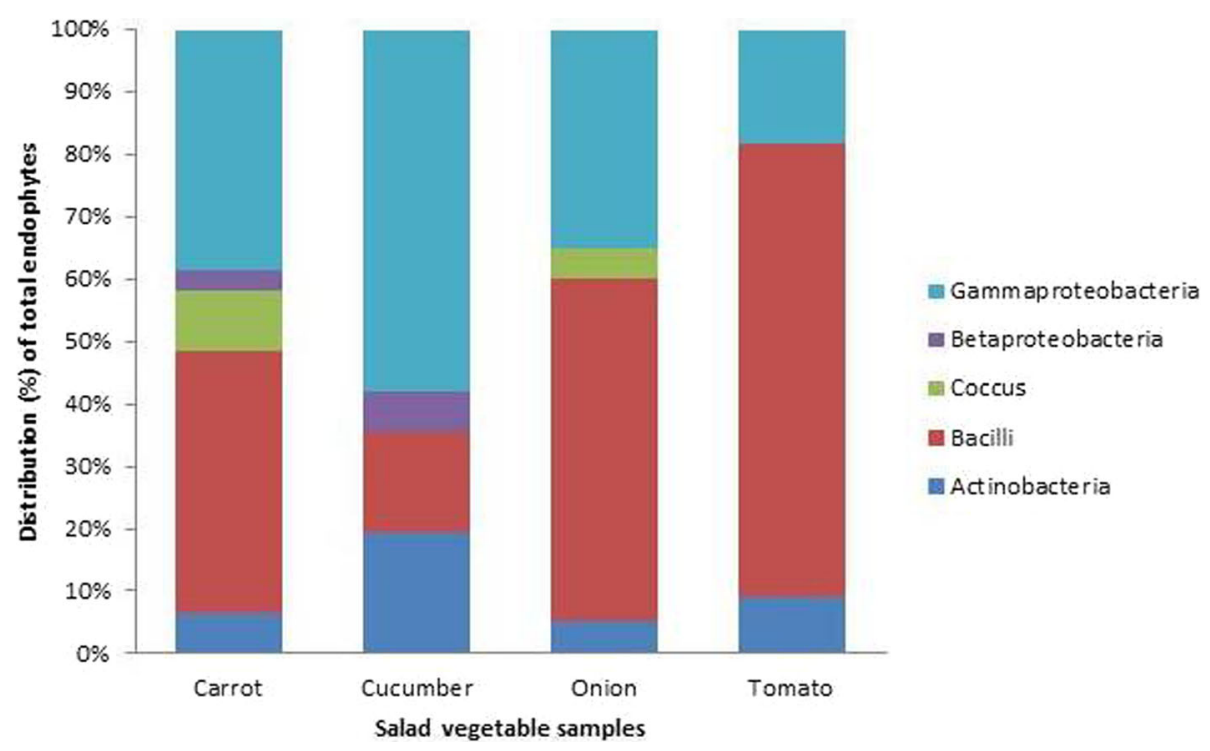

Fig. 3 Taxonomical distribution of endophytic bacteria in salad vegetables

accession numbers for each of the bacterial isolate along with details of their pathogen/non-pathogen nature (based on literature search) are presented in Table 2.

The diversity indices of the endophytic bacterial isolates from the four salad vegetables were calculated using the PAST program (Table 3). The diversity indices were calculated to obtain the diversity of bacterial isolates in the salad vegetables which revealed a lower diversity in tomato, whereas carrot had the highest bacterial diversity compared to other salad vegetables. Moreover, the Dominance (D) and Berger-Parker indices clearly showed that the single taxa of the salad vegetables (tomato) were abundant in the community and the number of isolates are shown in Table 3.

The isolates were further classified as human pathogens, human opportunistic pathogens, plant pathogens, plant beneficial, plant commensal and environmentally beneficial bacteria and represented as percentage occurrence in each vegetable type (Fig. 4). For this categorization, repeated occurrence of the same species was also counted and represented as percentage to the total population in a given vegetable. It was observed that human opportunistic pathogen was predominant in carrot and onion, whereas plant beneficial bacteria dominated in cucumber and tomato.

\section{Discussion}

In spite of potential beneficial aspects of salad vegetables, concerns over their safety and quality have risen since there are number of existing factors responsible for contamination. Fresh salad vegetables have little or no processing steps that can reduce the pathogen levels.

In general, plant harbours diverse bacterial populations both as epiphytes and endophytes, and they are classified based on their characteristics as plant associated bacteria, plant pathogenic, plant growth promoting bacteria and human pathogenic. The presence of bacterial populations as endophytes cannot be removed by washing and thus enters human during consumption of fresh produce as raw salads [9]. Vegetables are considered as the major reservoirs of opportunistic and emerging pathogens due to its diverse microbiome and they are also strongly influenced by biogeographic aspects of farming and food processing practices [10].

In United States, the importance and of fresh produce related infection was realized after the onset of shiga toxin producing $E$. coli outbreak related to fresh vegetables [11]. The ready-to-eat foods of non-animal origin such as, fruits, vegetables, salads, seeds, nuts, cereals, herbs, spices, fruits and algae had been reported to cause several foodborne outbreaks between 2007 to 2011, in which the major outbreak was with the combination of Salmonella spp. with leafy greens, bulb and stem of vegetables tomatoes and melons, and E. coli with fresh pods, legumes and grains [12]. Consumption of fresh produce raised the occurrence of gastroenteritis, caused by E. coli 0157:H7 and non-typhoidal Salmonella which were traditionally considered as non-hosts for human enteric pathogens. The occurrence of produce-associated outbreaks highlighted our deficiencies in understanding the ecology of enteric pathogens outside human and animal host [13].

The endophytic bacterial isolates observed in our study in tomato, onion, cucumber and carrot belonged to actinobacteria, firmicutes, betaproteobacteria, gammaproteobacteria, bacilli and cocci. The bacteria were categorized based on the known characteristics such as pathogens, non- 
Table 2 Endophytic bacterial isolates from salad vegetables and their known characteristics

\begin{tabular}{|c|c|c|c|c|c|}
\hline Bacterial isolate & Description $^{a}$ & Source vegetable & Isolate ID & Dilution & $\begin{array}{l}\text { GenBank } \\
\text { accession no. }\end{array}$ \\
\hline $\begin{array}{l}\text { Stenotrophomonas } \\
\text { maltophilia }\end{array}$ & $\begin{array}{l}\text { Opportunistic pathogen; associated with } \\
\text { conjunctivitis, keratitis, scleritis, dacryrocystitis, } \\
\text { cellulitis and endophthalmitis }\end{array}$ & $\begin{array}{l}\text { Carrot, } \\
\text { Carrot, } \\
\text { Carrot, } \\
\text { Carrot, } \\
\text { Onion, } \\
\text { Tomato }\end{array}$ & $\begin{array}{l}\text { SBANHCA1, } \\
\text { SBANHCa5, } \\
\text { SBANHCa6, } \\
\text { SBANHCa13, } \\
\text { SBANHO7, } \\
\text { SBANHT8 }\end{array}$ & $\begin{array}{l}\text { Crude, } \\
\text { Crude, } \\
\text { Crude, } \\
10^{-2}, \\
\text { Crude, } \\
\text { Crude }\end{array}$ & $\begin{array}{l}\text { KJ923784, } \\
\text { KJ923788, } \\
\text { KJ923789, } \\
\text { KJ923796, } \\
\text { KJ923776, } \\
\text { KR186173 }\end{array}$ \\
\hline $\begin{array}{l}\text { Staphylococcus } \\
\text { aureus }\end{array}$ & $\begin{array}{l}\text { Opportunistic pathogen; causes food poisoning, } \\
\text { skin infection, pneumonia, septicemia, pyogenic } \\
\text { infection, toxic shock syndrome and bacteremia }\end{array}$ & $\begin{array}{l}\text { Carrot, } \\
\text { Carrot, } \\
\text { Carrot, } \\
\text { Onion, } \\
\text { Tomato, }\end{array}$ & $\begin{array}{l}\text { SBANHCA2, } \\
\text { SBANHCa10, } \\
\text { SBANHCa11, } \\
\text { SBANHO2, } \\
\text { SBANHT3, }\end{array}$ & $\begin{array}{l}\text { Crude, } \\
\text { Crude, } \\
10^{-2}, \\
\text { Crude, } \\
\text { Crude, }\end{array}$ & $\begin{array}{l}\text { KJ923785, } \\
\text { KJ923793, } \\
\text { KJ923794, } \\
\text { KJ923771, } \\
\text { KR186184, }\end{array}$ \\
\hline $\begin{array}{l}\text { Terribacillus } \\
\text { saccharophilus }\end{array}$ & Plant growth promoting rhizobacteria & Tomato & SBANST6 & Crude & KR259242 \\
\hline Bacillus tequilensis & Plant growth promoting bacteria; nitrogen fixing & Tomato & SBANST6a & Crude & KR259246 \\
\hline Salmonella enterica & $\begin{array}{l}\text { Highly pathogenic; causes food and water borne } \\
\text { disease in human and animals; causes } \\
\text { gastroenteritis, bacteraemia, enteric fever }\end{array}$ & $\begin{array}{l}\text { Carrot, } \\
\text { Carrot }\end{array}$ & $\begin{array}{l}\text { SBANHCA3, } \\
\text { SBANHCa4 }\end{array}$ & $\begin{array}{l}\text { Crude, } \\
\text { Crude }\end{array}$ & $\begin{array}{l}\text { KJ923786, } \\
\text { KJ923787 }\end{array}$ \\
\hline $\begin{array}{l}\text { Enterobacter } \\
\text { aerogenes }\end{array}$ & $\begin{array}{l}\text { Opportunistic pathogen; causes urinary tract } \\
\text { infection, bacteraemia, endocarditis, septic arthritis, } \\
\text { osteomyelitis and skin/soft tissue infection }\end{array}$ & $\begin{array}{l}\text { Carrot, } \\
\text { Carrot }\end{array}$ & $\begin{array}{l}\text { SBANHCA7, } \\
\text { SBANHCA9 }\end{array}$ & $\begin{array}{l}\text { Crude, } \\
\text { Crude }\end{array}$ & $\begin{array}{l}\text { KJ923790, } \\
\text { KJ923792 }\end{array}$ \\
\hline $\begin{array}{l}\text { Bordetella } \\
\text { bronchiseptica }\end{array}$ & $\begin{array}{l}\text { Opportunistic pathogen; causes respiratory tract } \\
\text { infection in patients with cystic fibrosis and } \\
\text { whooping cough }\end{array}$ & Carrot & SBANHCa8 & Crude & KJ923791 \\
\hline Bacillus pumilus & $\begin{array}{l}\text { Plant growth promoting bacteria; opportunistic } \\
\text { pathogen; causes food poisoning and cutaneous } \\
\text { infection in human. }\end{array}$ & $\begin{array}{l}\text { Carrot, } \\
\text { Carrot, } \\
\text { Carrot, } \\
\text { Carrot, } \\
\text { Carrot, } \\
\text { Onion, } \\
\text { Onion, } \\
\text { Onion, } \\
\text { Onion, } \\
\text { Tomato, } \\
\text { Tomato, } \\
\text { Tomato, } \\
\text { Tomato, } \\
\text { Tomato, } \\
\text { Tomato }\end{array}$ & $\begin{array}{l}\text { SBANHCa12, } \\
\text { SBANHCA15, } \\
\text { SBANHCa15a, } \\
\text { SBANHCA17, } \\
\text { SBANHCa17a, } \\
\text { SBANHO1, } \\
\text { SBANHO4, } \\
\text { SBANHO12, } \\
\text { SBANSO81, } \\
\text { SBANHT1, } \\
\text { SBANHT16, } \\
\text { SBANHT17, } \\
\text { SBANHT21, } \\
\text { SBANST8, } \\
\text { SBANST12 }\end{array}$ & $\begin{array}{l}10^{-2}, \\
10^{\prime}{ }^{\prime} \\
10^{-2}, \\
10^{-2}, \\
10^{-2}, \\
\text { Crude, } \\
\text { Crude, } \\
10^{-4} \text {, } \\
\text { Crude, } \\
\text { Crude, } \\
10^{-2}{ }^{\prime} \\
10^{-3} \\
10^{-4^{\prime}} \\
10^{-2}, \\
10^{-2}\end{array}$ & $\begin{array}{l}\text { KJ923795, } \\
\text { KJ923798, } \\
\text { KR152298, } \\
\text { KJ923800, } \\
\text { KR152300, } \\
\text { KJ923770, } \\
\text { KJ923773, } \\
\text { KJ923780, } \\
\text { KR259236, } \\
\text { KR186170, } \\
\text { KR186180, } \\
\text { KR186181, } \\
\text { KR186183, } \\
\text { KR259243, } \\
\text { KR259245 }\end{array}$ \\
\hline $\begin{array}{l}\text { Pseudomonas } \\
\text { aeruginosa }\end{array}$ & $\begin{array}{l}\text { Pathogenic; causes infection in immunocompromised } \\
\text { individuals; causes endocarditis, osteomyelitis, } \\
\text { pneumonia, urinary tract infection, gastrointestinal } \\
\text { infections and meningitis }\end{array}$ & Carrot & $\begin{array}{l}\text { SBANHCa1a, } \\
\text { SBANHCA14 }\end{array}$ & $\begin{array}{l}\text { Crude, } \\
10^{-2}\end{array}$ & $\begin{array}{l}\text { KR152296, } \\
\text { KJ923797 }\end{array}$ \\
\hline $\begin{array}{l}\text { Paenibacillus } \\
\text { polymyxa }\end{array}$ & $\begin{array}{l}\text { Plant growth promoting bacteria; biocontrol agent } \\
\text { and suppresses plant pathogens }\end{array}$ & Carrot & SBANHCA16 & $10^{-2}$ & KJ923799 \\
\hline $\begin{array}{l}\text { Paenibacillus } \\
\text { illinoisensis }\end{array}$ & $\begin{array}{l}\text { Plant growth promoting rhizobacteria; suppresses } \\
\text { the activity of pathogens }\end{array}$ & Carrot & SBANHCa16a & $10^{-2}$ & KR152299 \\
\hline $\begin{array}{l}\text { Enterobacter } \\
\text { hormaechei }\end{array}$ & $\begin{array}{l}\text { Causes nosocomial infection associated with blood } \\
\text { stream infection }\end{array}$ & Carrot & SBANHCa2a & Crude & KR152301 \\
\hline $\begin{array}{l}\text { Staphylococcus } \\
\text { sciuri }\end{array}$ & $\begin{array}{l}\text { Animal associated bacteria; causes endocarditis, } \\
\text { peritonitis, septic shock, urinary tract infection, } \\
\text { endophthalmitis, pelvic inflammatory disease and } \\
\text { wound infection }\end{array}$ & $\begin{array}{l}\text { Carrot, } \\
\text { Carrot }\end{array}$ & $\begin{array}{l}\text { SBANHCa7a, } \\
\text { SBANHCa14a }\end{array}$ & $\begin{array}{l}\text { Crude, } \\
10^{-2}\end{array}$ & KR152302 \\
\hline Bacillus aerophilus & Bioremediation of imidacloprid, a synthetic insecticide & Carrot & SBANSCa3 & Crude & KR186185 \\
\hline Bacillus cereus & Causes food poisoning; vomiting and diarrhoea & Carrot & SBANSCa4 & Crude & KR186186 \\
\hline $\begin{array}{l}\text { Microbacterium } \\
\text { oleivorans }\end{array}$ & $\begin{array}{l}\text { Plant beneficial bacteria; biocontrol agent to reduce } \\
\text { mycotoxin in peanuts, grapes and cereals }\end{array}$ & Carrot & SBANSCa5 & Crude & KR186187 \\
\hline Arthrobacter & Environmentally beneficial bacteria; biodegradation & Carrot & SBANSCa6 & Crude & KR186188 \\
\hline
\end{tabular}

nicotianae 
Table 2 Endophytic bacterial isolates from salad vegetables and their known characteristics (Continued)

\begin{tabular}{|c|c|c|c|c|c|}
\hline Bacillus subtilis & $\begin{array}{l}\text { Plant beneficial bacteria; suppresses cucumber } \\
\text { Fusarium wilt disease }\end{array}$ & Carrot & SBANSCa7 & Crude & KR186189 \\
\hline Bacillus flexus & $\begin{array}{l}\text { Plant endophytic bacteria; present in roots of } \\
\text { wheat crop. }\end{array}$ & $\begin{array}{l}\text { Carrot, } \\
\text { Onion, }\end{array}$ & $\begin{array}{l}\text { SBANSCa10, } \\
\text { SBANSO82, }\end{array}$ & $\begin{array}{l}10^{-2} \\
\text { Crude, }\end{array}$ & $\begin{array}{l}\text { KR186190, } \\
\text { KR259237, }\end{array}$ \\
\hline $\begin{array}{l}\text { Stenotrophomonas } \\
\text { rhizophila }\end{array}$ & $\begin{array}{l}\text { Promotes plant growth; protects against biotic } \\
\text { and abiotic stress; associated with human as a } \\
\text { nosocomial pathogen }\end{array}$ & $\begin{array}{l}\text { Cucumber, } \\
\text { Cucumber, } \\
\text { cucumber, } \\
\text { Cucumber, } \\
\text { Cucumber, } \\
\text { Cucumber, } \\
\text { cucumber, } \\
\text { cucumber }\end{array}$ & $\begin{array}{l}\text { SBANHCu14a, } \\
\text { SBANHCu15, } \\
\text { SBANHCu15a, } \\
\text { SBANHCu16, } \\
\text { SBANHCu17, } \\
\text { SBANHCu17a, } \\
\text { SBANHCu23, } \\
\text { SBANHCu23a }\end{array}$ & $\begin{array}{l}10^{-2} \\
10^{-2} \\
10^{-3^{\prime}} \\
10^{-3} \\
10^{-4} \\
10^{-4} \\
10^{-4} \\
10^{-4}\end{array}$ & $\begin{array}{l}\text { KR259223, } \\
\text { KR259224, } \\
\text { KT020946, } \\
\text { KR152303, } \\
\text { KT020947, } \\
\text { KR259225, } \\
\text { KT020952, } \\
\text { KR152304 }\end{array}$ \\
\hline $\begin{array}{l}\text { Arthrobacter } \\
\text { mysorens }\end{array}$ & Causes erythema with localised skin infection & Cucumber & SBANHCu24 & $10^{-4}$ & KR152305 \\
\hline $\begin{array}{l}\text { Pseudomonas } \\
\text { xanthomarina }\end{array}$ & $\begin{array}{l}\text { Arsenite oxidizing bacteria; helps in biodegradation } \\
\text { of petroleum oil }\end{array}$ & $\begin{array}{l}\text { Cucumber, } \\
\text { Cucumber, } \\
\text { Cucumber, } \\
\text { Cucumber, } \\
\text { Cucumber }\end{array}$ & $\begin{array}{l}\text { SBANHCu19, } \\
\text { SBANHCu22, } \\
\text { SBANHCu25a, } \\
\text { SBANSCu19, } \\
\text { SBANSCu22 }\end{array}$ & $\begin{array}{l}10^{-3} \\
10^{-4} \\
10^{-4} \\
10^{-2} \\
10^{-4}\end{array}$ & $\begin{array}{l}\text { KT020948, } \\
\text { KT020951, } \\
\text { KR152306, } \\
\text { KR259226, } \\
\text { KR259229 }\end{array}$ \\
\hline $\begin{array}{l}\text { Cellulosimicrobium } \\
\text { cellulans }\end{array}$ & $\begin{array}{l}\text { Opportunistic pathogen; causes catheter related } \\
\text { bacteraemia with short bowel syndrome in children, } \\
\text { peritonitis, endocarditis and joint, ocular and } \\
\text { soft-tissue infections }\end{array}$ & Cucumber & SBANHCu10 & Crude & KT020943 \\
\hline $\begin{array}{l}\text { Microbacterium } \\
\text { schleiferi }\end{array}$ & $\begin{array}{l}\text { Environmentally beneficial bacteria; helps in } \\
\text { bioremediation of 1, 3,5-TMB (trimethylebenzene) }\end{array}$ & Cucumber & SBANHCu12 & $10^{-2}$ & KT020944 \\
\hline $\begin{array}{l}\text { Xanthomonas } \\
\text { axonopodis }\end{array}$ & $\begin{array}{l}\text { Plant pathogenic bacteria; causes bacterial pustule } \\
\text { disease in soybean }\end{array}$ & Cucumber & SBANHCU14 & $10^{-2}$ & KT020945 \\
\hline $\begin{array}{l}\text { Pseudomonas } \\
\text { stutzeri }\end{array}$ & $\begin{array}{l}\text { Opportunistic pathogen; causes community acquired } \\
\text { pneumonia, meningitis, neonatal septicaemia and } \\
\text { knee arthritis in children }\end{array}$ & $\begin{array}{l}\text { Cucumber, } \\
\text { Onion, } \\
\text { Onion, } \\
\text { Onion, } \\
\text { Onion, } \\
\text { Onion, } \\
\text { Tomato }\end{array}$ & $\begin{array}{l}\text { SBANHCu20, } \\
\text { SBANHO3, } \\
\text { SBANHO5, } \\
\text { SBANHO8, } \\
\text { SBANHO13, } \\
\text { SBANHO14, } \\
\text { SBANHT4 }\end{array}$ & $\begin{array}{l}10^{-3}, \\
\text { Crude, } \\
\text { Crude, } \\
10^{-2}, \\
10^{-3} \\
10^{-3}, \\
\text { Crude }\end{array}$ & $\begin{array}{l}\text { KT020949, } \\
\text { KJ923772, } \\
\text { KJ923774, } \\
\text { KJ923777, } \\
\text { KJ923781, } \\
\text { KJ923782, } \\
\text { KR186171 }\end{array}$ \\
\hline $\begin{array}{l}\text { Achromobacter } \\
\text { xylosoxidans }\end{array}$ & $\begin{array}{l}\text { Opportunistic pathogen; causes malignancies, cardiac } \\
\text { disease, meningitis, urinary tract infections, abscesses, } \\
\text { osteomyelitis, corneal ulcers, prosthetic valve } \\
\text { endocarditis, peritonitis and pneumonia }\end{array}$ & $\begin{array}{l}\text { Cucumber, } \\
\text { Cucumber }\end{array}$ & $\begin{array}{l}\text { SBANHCu21, } \\
\text { SBANSCU21 }\end{array}$ & $\begin{array}{l}10^{-3} \\
10^{-4}\end{array}$ & $\begin{array}{l}\text { KT020950, } \\
\text { KR259228 }\end{array}$ \\
\hline $\begin{array}{l}\text { Arthrobacter } \\
\text { protophormiae }\end{array}$ & $\begin{array}{l}\text { Opportunistic pathogen; present in human skin as } \\
\text { commensals; widely distributed in pesticide } \\
\text { contaminated agricultural fields }\end{array}$ & Cucumber & SBANHCu24a & $10^{-4}$ & KT020953 \\
\hline $\begin{array}{l}\text { Pseudomonas } \\
\text { indoloxydans }\end{array}$ & $\begin{array}{l}\text { Useful in biological synthesis of indigo, an important } \\
\text { dye-stuff used in textile industries }\end{array}$ & Cucumber & SBANHCu25 & $10^{-4}$ & KT020954 \\
\hline $\begin{array}{l}\text { Aeromonas } \\
\text { hydrophila }\end{array}$ & $\begin{array}{l}\text { Opportunistic pathogen; causes enteritis, wound } \\
\text { infection, septicaemia, pneumonia and conjunctivitis }\end{array}$ & Cucumber & SBANHCU11 & Crude & KU564062 \\
\hline $\begin{array}{l}\text { Geobacillus } \\
\text { stearothermophilus }\end{array}$ & $\begin{array}{l}\text { Persists as contaminant in canned food; used as } \\
\text { biological indicator for deactivation of pathogens }\end{array}$ & Cucumber & SBANSCU4 & Crude & KR259230 \\
\hline $\begin{array}{l}\text { Staphylococcus } \\
\text { haemolyticus }\end{array}$ & $\begin{array}{l}\text { Highly pathogenic; most frequently isolated from } \\
\text { blood culture }\end{array}$ & Cucumber & SBANSCU7 & Crude & KR259231 \\
\hline Bacillus aerius & $\begin{array}{l}\text { Halophilic endophytic bacteria; plant growth } \\
\text { promotion, phosphate solubilisation, bioremediation } \\
\text { of salt affected soil }\end{array}$ & Cucumber & SBANSCu8 & Crude & KR259232 \\
\hline $\begin{array}{l}\text { Bacillus } \\
\text { megaterium }\end{array}$ & $\begin{array}{l}\text { Plant beneficial bacteria; helps in nitrogen fixation } \\
\text { and promotes plant growth }\end{array}$ & $\begin{array}{l}\text { Cucumber, } \\
\text { Cucumber }\end{array}$ & $\begin{array}{l}\text { SBANSCu9, } \\
\text { SBANSCu11 }\end{array}$ & $\begin{array}{l}\text { Crude, } \\
10^{-2}\end{array}$ & $\begin{array}{l}\text { KR259220, } \\
\text { KR259233, }\end{array}$ \\
\hline $\begin{array}{l}\text { Microbacterium } \\
\text { arborescens }\end{array}$ & Rhizosphere bacteria of sand dune plant & $\begin{array}{l}\text { Cucumber, } \\
\text { Cucumber, } \\
\text { Onion, } \\
\text { Tomato }\end{array}$ & $\begin{array}{l}\text { SBANSCU10, } \\
\text { SBANHCu12a, } \\
\text { SBANSO80, } \\
\text { SBANHT19 }\end{array}$ & $\begin{array}{l}\text { Crude, } \\
10^{-2} \\
\text { Crude, } \\
10^{-4}\end{array}$ & $\begin{array}{l}\text { KR259221, } \\
\text { KR259222, } \\
\text { KR259235, } \\
\text { KR186182 }\end{array}$ \\
\hline
\end{tabular}


Table 2 Endophytic bacterial isolates from salad vegetables and their known characteristics (Continued)

\begin{tabular}{|c|c|c|c|c|c|}
\hline $\begin{array}{l}\text { Pseudomonas } \\
\text { fluorescens }\end{array}$ & $\begin{array}{l}\text { Plant beneficial rhizobacteria; causes red skin disease } \\
\text { with skin hemorrhage and ulceration }\end{array}$ & Cucumber & SBANSCU20 & $10^{-3}$ & KR259227 \\
\hline $\begin{array}{l}\text { Xanthomonas } \\
\text { fuscans }\end{array}$ & $\begin{array}{l}\text { Plant pathogenic bacteria; infects rice, banana, citrus, } \\
\text { bean, tomato, pepper, sugarcane and wheat }\end{array}$ & $\begin{array}{l}\text { Onion, } \\
\text { Tomato }\end{array}$ & $\begin{array}{l}\text { SBANHO6, } \\
\text { SBANHT7 }\end{array}$ & $\begin{array}{l}\text { Crude, } \\
\text { Crude }\end{array}$ & $\begin{array}{l}\text { KJ923775, } \\
\text { KR186172 }\end{array}$ \\
\hline $\begin{array}{l}\text { Listeria } \\
\text { monocytogenes }\end{array}$ & $\begin{array}{l}\text { Food borne pathogen; causes bacterial meningitis, } \\
\text { multiple cerebral ring enhancing lesions }\end{array}$ & $\begin{array}{l}\text { Onion, } \\
\text { Tomato, } \\
\text { Tomato, } \\
\text { Tomato }\end{array}$ & $\begin{array}{l}\text { SBANHO9, } \\
\text { SBANHT9 } \\
\text { SBANHT14, } \\
\text { SBANHT15 }\end{array}$ & $\begin{array}{l}10^{-2}, \\
\text { Crude, } \\
10^{-2} \\
10^{-2}\end{array}$ & $\begin{array}{l}\text { KJ923778, } \\
\text { KR186174, } \\
\text { KR186178, } \\
\text { KR186179 }\end{array}$ \\
\hline Bacillus anthracis & $\begin{array}{l}\text { Obligate pathogen; causes anthrax: inhalation, } \\
\text { gastrointestinal and cutaneous }\end{array}$ & $\begin{array}{l}\text { Onion, } \\
\text { Tomato, } \\
\text { Tomato }\end{array}$ & $\begin{array}{l}\text { SBANHO11, } \\
\text { SBANHT10, } \\
\text { SBANHT12 }\end{array}$ & $\begin{array}{l}10^{-2} \\
\text { Crude, } \\
10^{-2}\end{array}$ & $\begin{array}{l}\text { KJ923779, } \\
\text { KR186175, } \\
\text { KR186176 }\end{array}$ \\
\hline $\begin{array}{l}\text { Staphylococcus } \\
\text { epidermidis }\end{array}$ & $\begin{array}{l}\text { Opportunistic pathogen; causes cardiovascular, CNS } \\
\text { shunts, joints, blood stream infection and } \\
\text { nosocomial infection }\end{array}$ & Onion, & SBANHO15, & $10^{-3}$ & KJ923783, \\
\hline $\begin{array}{l}\text { Staphylococcus } \\
\text { gallinarum }\end{array}$ & $\begin{array}{l}\text { Rare human pathogen; causes abdominal pain, } \\
\text { nausea and weakness }\end{array}$ & $\begin{array}{l}\text { Onion, } \\
\text { Tomato }\end{array}$ & $\begin{array}{l}\text { SBANSO90, } \\
\text { SBANHT11 }\end{array}$ & $\begin{array}{l}10^{-3} \\
10^{-2}\end{array}$ & $\begin{array}{l}\text { KR259239, } \\
\text { KU564061 }\end{array}$ \\
\hline $\begin{array}{l}\text { Enterococcus } \\
\text { faecium }\end{array}$ & $\begin{array}{l}\text { Opportunistic pathogen; causes urinary tract, wound } \\
\text { and soft tissue infections, bacteraemia, endocarditis }\end{array}$ & $\begin{array}{l}\text { Onion, } \\
\text { Tomato }\end{array}$ & $\begin{array}{l}\text { SBANSO54, } \\
\text { SBANST3 }\end{array}$ & $\begin{array}{l}\text { Crude, } \\
\text { Crude }\end{array}$ & $\begin{array}{l}\text { KR259234, } \\
\text { KR259241 }\end{array}$ \\
\hline Bacillus aryabhattai & Plant growth promoting bacteria & $\begin{array}{l}\text { Onion, } \\
\text { Tomato, } \\
\text { Tomato }\end{array}$ & $\begin{array}{l}\text { SBANSO83, } \\
\text { SBANST7, } \\
\text { SBANST11 }\end{array}$ & $\begin{array}{l}10^{-2} \\
\text { Crude, } \\
10^{-2}\end{array}$ & $\begin{array}{l}\text { KR259238, } \\
\text { KR259240, } \\
\text { KR259244 }\end{array}$ \\
\hline
\end{tabular}

a References of description are given in discussion section

pathogens and beneficial. Previous reports on the occurrence of human enteric pathogens in salad vegetables were based mostly on enrichment cultures. The bacterial isolates we obtained in the present study were either from crude extract or dilutions up to $10^{-4}$. Without enrichment, the average percentage of human pathogens obtained in salad vegetables was $16.25 \%$ and of human opportunistic pathogens were $26.5 \%$ of the total endophytic isolates. This represents high level of contamination with pathogenic bacteria in the salad vegetables studied. In India, particularly in Tamil Nadu, domestic sewage, industrial and municipal waste water is used for irrigating vegetable crops. This could be one of the reasons for the human pathogenic bacterial load observed in salad vegetables, in addition to possible other reasons including contamination through human and farm animal waste in agricultural lands, postharvest handling, transport, storage and poor hygiene conditions prevailing in market places.

Table 3 Diversity indices of endophytic bacterial population of the salad vegetables

\begin{tabular}{|c|c|c|c|c|c|}
\hline Diversity indices/parameters & Formula & Carrot & Cucumber & Onion & Tomato \\
\hline Taxa (S) & - & 5 & 4 & 4 & 3 \\
\hline Individuals (n) & - & 31 & 30 & 20 & 21 \\
\hline Dominance (D) & $D=\operatorname{Sum}\left(n_{i} / n\right)^{2}$ & 0.3403 & 0.3933 & 0.43 & 0.61 \\
\hline Simpson (1-D) & $1-D=1-\operatorname{Sum}\left(n_{i} / n\right)^{2}$ & 0.6597 & 0.6067 & 0.57 & 0.39 \\
\hline Shannon $(H)$ & $H=\operatorname{Sum}\left(\left(n_{i} / n\right) \operatorname{In}\left(n_{i} / n\right)^{\prime}\right.$ & 1.245 & 1.123 & 0.9958 & 0.7091 \\
\hline Evenness (E) & $E=e^{H} / S$ & 0.6949 & 0.7684 & 0.6767 & 0.6774 \\
\hline Brillouin (HB) & $H B=\ln (n)-\operatorname{Sum} \ln \left(n_{i}\right)$ & 1.067 & 0.9698 & 0.8154 & 0.5821 \\
\hline Menhinick (db) & $\mathrm{db}=\mathrm{S} / \sqrt{n}$ & 0.898 & 0.7303 & 0.8944 & 0.6547 \\
\hline Margalef (Ma) & $M a=(S-1) / \ln (n)$ & 1.165 & 0.882 & 1.001 & 0.6569 \\
\hline Equitability (J) & $\mathrm{J}=\mathrm{H} / \mathrm{H} \max$ & 0.7738 & 0.81 & 0.7183 & 0.6455 \\
\hline Fisher alpha (FA) & $S=a^{*} \ln (1+n / a)$ & 1.687 & 1.24 & 1.504 & 0.9578 \\
\hline Berger-Parker (d) & $\mathrm{d}=\mathrm{n} / \mathrm{nT}$ & 0.4194 & 0.5667 & 0.55 & 0.7619 \\
\hline Chao-1 & Chao $1=S+F_{1}\left(F_{1}-1\right) /\left(2\left(F_{2}+1\right)\right)$ & 5 & 4 & 5 & 3 \\
\hline
\end{tabular}

$n=$ number of individuals; $n_{\mathrm{i}}=$ number of individuals of taxon $\mathrm{i} ; \mathrm{S}=$ number of taxa; $\mathrm{nT}=$ number of individuals in the dominant taxon $\mathrm{Hmax}=\log \mathrm{S}$ 


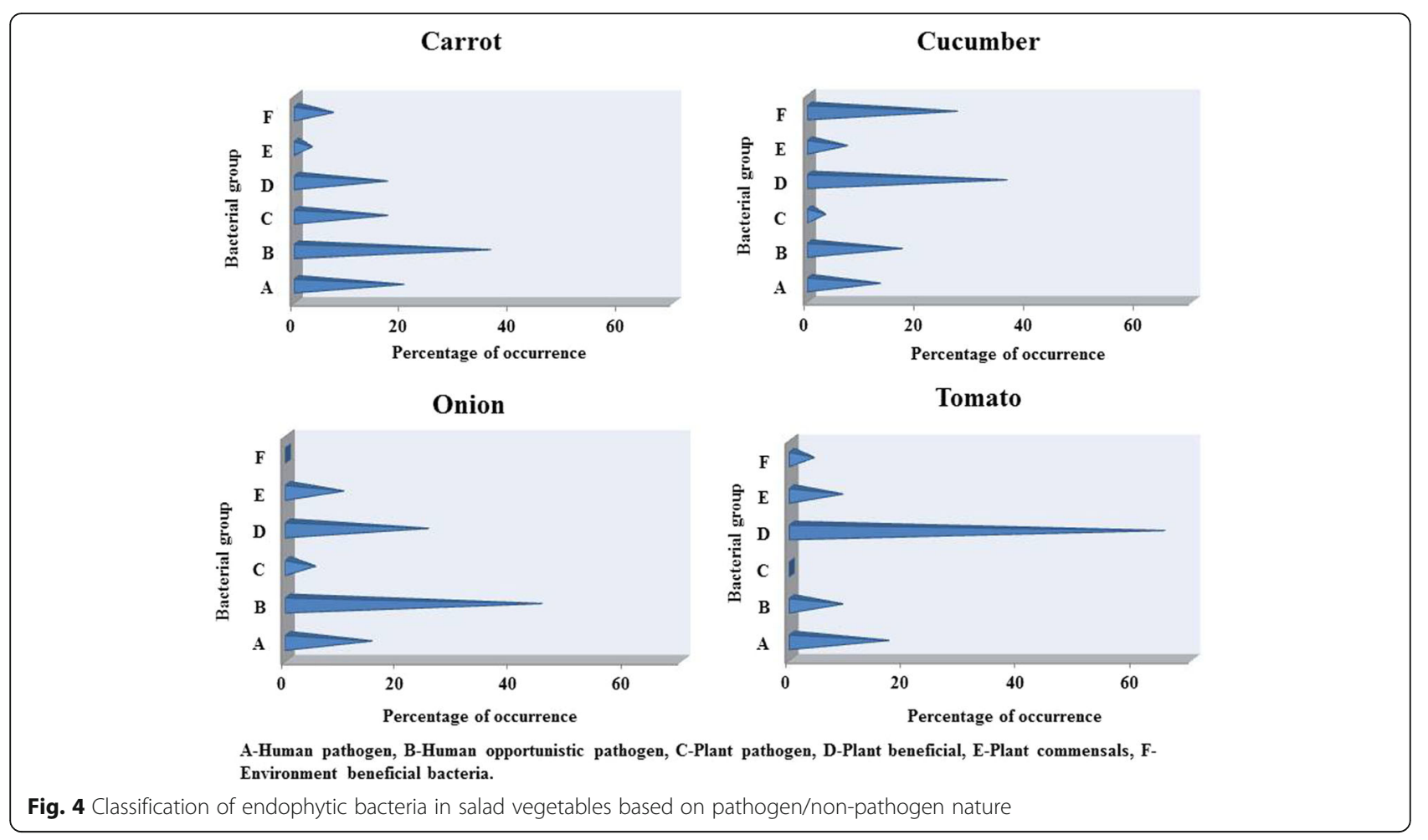

Viswanathan and Kaur [14] has reported existence of P. aeruginosa, E. coli, S. aureus, Enterobacter sp., Salmonella sp. in carrot. E. coli and S. enterica are known to adapt and persist in plant environment and increase the chance of transmitting to humans via consumption of plants or plant-derived products [15]. The ready-toeat salads and ready-to-eat sprouts are known to be major vehicle for non-tuberculosis Mycobacteria transmission in humans [16]. Endophytic microorganisms associated with carrot, cucumber, cabbage and onions were analysed by Tayo et al. [1] and E. coli was found to be more predominant, followed by Enterobacter sp., $S$. aureus, Erwinia sp., Pseudomonas sp. and Salmonella sp.

Among the bacteria that were identified in our study across four vegetables, major genera were Bacillus followed by Staphylococcus, Pseudomonas and Microbacterium. Occurrence of Bacillus aerius was unique to cucumber, similarly $B$. tequilensis to tomato, $B$. anthracis and $B$. aryabhattai to onion. B. pumilus and B. flexus were found to occur in carrot, onion and tomato. We have previously reported the endophytic colonization of B. pumilus in apples, B. flexus and B. subtilis in oranges [17]. B. aryabhattai [18], Terribacillus saccharophilus [19] and B. tequilensis [20] are bacterial strains isolated from the upper atmospheric air of field soils in Japan and 2000-year old Mexican shaft-tomb. B. cereus is an opportunistic pathogen causing food poison [21]. $B$. anthracis is an obligate pathogen, which survive in several environmental conditions as saprobionts and known to be involved in horizontal gene transfer in plant rhizosphere [22]. Geobacillus stearothermophilus produces lactic acid by fermenting potato starch and potato residues [23]. Paenibacillus illinoisensis has been reported to suppress the activity of antioxidative enzymes in pepper roots caused by Phytophthora capsici infection [24].

In the present study, Staphylococcus sciuri was found to occur only in carrot, S. epidermidis in onion and $S$. haemolyticus in cucumber. S. aureus was obtained from carrot as well as onion and S. gallinarium from onion as well as tomato. S. aureus is considered as a commensal and a pathogen in human [25]. S. sciuri, animal associated bacteria, is known to be present widely on the skin and mucous surface of pet and farm animals and also in soil, sand, water and marsh grass. The presence of $S$. sciuri, its adaptation and continuous existence in hospital environment has also been reported [26]. S. epidermidis has been reported as an important human opportunistic pathogen causing infection in cardiovascular, CNS shunts, joints, blood stream etc. [27]. S. haemolyticus is an important hospital acquired pathogen, frequently isolated from human blood cultures [28]. S. gallinarum, a rare human pathogen has been isolated from chicken and saliva of healthy humans [29].

Four among the five species of Pseudomonas observed in our study $(P$. aeruginosa, $P$. xanthomarina, $P$. indolox$y$ dans and $P$. fluorescens) were from cucumber only. $P$. stutzeri was found in cucumber and onion. Pseudomonas fluorescens is known to display plant growth promoting 
rhizobacterial (PGPR) activity [30]. It has been isolated from rhizosphere soils of many crop plants and has received the most research attention among the known PGPR genera. In human, it is a less virulent bacterium causing nosocomial infections in immune-compromised patients [31]. Hu et al. [32] has reported it as a common aquaculture pathogen. P. stutzeri causes knee arthritis in children [33]. P. xanthomarine has been reported as a novel bacteria isolated from marine ascidian [34] and from arsenic contaminated soil [35]. P. stutzeri and P. xanthomarine has the highest biodegrading ability to degrade crude petroleum oil [36]. P. indoloxydans is a lindane (chlorinated pesticide) degrading bacteria isolated from soils of lindane manufacturing industrial site [37].

We also observed Microbacterium oleivorans in carrot, M. schleiferi in cucumber, M. testaceum in tomato and $M$. arborescens in cucumber and onion. M. testaceum [38] is an environment friendly bacterium which helps in improving the plant growth and yield of crops by suppressing the growth of plant pathogens. M. oleovorans has been reported as a biocontrol agent against Fusarium verticillioides and Aspergillus flavus [39].

Cellulosimicrobium cellulans which was observed in cucumber and tomato tissues is a rare human pathogen, causing septic arthritis mainly in immune-compromised patients [40]. In cucumber plants, it supresses the selftoxic effect by degrading cinnamic acid, benzoic acid, paraaminobenzoic acid and phenol, helps in nutrient absorption rate, adjusts microbial groups in nonrhizospheric soil, thus increasing the number of beneficial bacteria and decreasing fungal growth [41]. Thus, in spite of being a human pathogen, C. cellulans can also act as biocontrol agent for plant pathogens. Stenotrophomonas maltophila has been reported from cucumber rhizosphere involved in supressing Phytophthora crown rot [42]. We observed S. maltophila in carrot and $S$. rhizophila in cucumber and tomato indicating the species specificity of the bacteria according to the vegetable specific endosphere.

Salmonella enterica is an important foodborne human pathogen, which has the ability to colonize number of plant species such as, Arabidopsis, alfalfa, tomato and various leafy green vegetables [43]. Salmonella triggers mutation in pathogen associated molecular patterns (PAMP) motifs to escape plant defence and it also expresses effectors in the plant tissues to manipulate the plant immune system by triggering PTI (PAMP- triggered immunity) to evolve strategies to avoid or subvert plant immunity [43]. An increase in the growth of $S$. enteritidis has been reported in melon, watermelon and papaya at different temperatures $\left(10,20\right.$ and $\left.30^{\circ} \mathrm{C}\right)$ [44]. The proliferation of Salmonella is high on red ripped tomato tissues compared to green tomato tissues [45]. It attaches to stem and flowers of tomato plant and remains viable during development of fruit and serves as a route cause for the contamination of tomato fruits [46].

Listeria monocytogenes, Aeromonas hydrophila and Clostridium botulinum have been considered as the most notable pathogens which maintain their infection potential under mild preservation conditions. A. hydrophila has the potential to grow at $0{ }^{\circ} \mathrm{C}$ and the temperature of $4-5{ }^{\circ} \mathrm{C}$ supports the growth in foods. $L$. monocytogenes survives in ready-to-eat fresh salads and causes public health risk [47]. Exiguobacterium acetylicum has been reported as an aetiological agent of bacteraemia in humans [48]. Whereas in wheat plants, it improves the growth of seedlings and inhibits the growth of plant pathogens and it is also a cold tolerant bacteria [49]. Bordetella bronchiseptica infects mainly immune-suppressed populations of humans and causes respiratory tract related disease in dogs, cats and rabbits [50]. Arthrobacter protophormiae, when pre-exposed to lower concentration of ONB (O- nitrobenzoate) and PHB (p- hydroxybenzoate) will change its cellular fatty acid profile and adapt itself to survive in high concentration of ONB and PHB [51]. A. mysorens causes erythema characterized by localized skin infection [52]. A. xylosoxidans was reported to be associated with number of outbreaks related to various infections such as malignancies, cardiac disease, meningitis, endocarditis, and pneumonia with number of death cases [53]. Enterobacter hormaechei a unique species was first identified in 1989 followed by several outbreaks on sepsis in neonatal intensive care units in Brazil and USA [54]. E. aerogenes and E. cloacae has been reported in hospital acquired infections in Europe and France, and they also have strong antibiotic resistance, which helps in colonizing multiple environments and hosts [55]. E. asburiae, epiphytic bacteria, exists as parasitic or commensal with in plant host and produce virulence factors based on their quorum sensing activity and has been isolated from soil, water, food products and lettuce leaves [56]. The type III secretion system (T3SS) encoded by hrp gene in plant associated bacteria Xanthomonas fuscans sub sp. fuscans is responsible for colonizing bean plants and causing bacterial blight disease [57]. Plant pathogenic bacterium Xanthomonas axonopodis cause bacterial pustule disease in soybean [58].

Surette et al. [59] enumerated the endophytic bacteria in carrot and found $83 \%$ of the strains were plant growth promoting bacteria. In our study, carrot contained more of human opportunistic pathogens followed by human pathogens, plant beneficial and plant pathogenic bacteria. In carrot, population of human opportunistic pathogens were high and approximately double the number of plant pathogens and plant beneficial bacteria. The scenario was the other way around in cucumber, where plant beneficial bacterial population was double and more than double the population of human opportunistic and human pathogens, 
respectively. In onion, human opportunistic pathogen population was high compared to plant beneficial. Tomato had a comparatively very high population of beneficial bacteria in which the human pathogens and plant pathogens were found to be drastically reduced. Comparing the functional diversity in all four vegetables, existence of high population of plant beneficial bacteria has suppressed the growth of human pathogens, human opportunistic pathogens and plant pathogens. Whether the difference in bacterial population between pathogens and non-pathogens is due to the suppression effect of plant beneficial bacteria on human opportunistic pathogens or suppression effect of human opportunistic pathogens on plant beneficial bacteria needs further in-depth analysis of their interaction in this ecological niche.

It is also interesting to note that population of human pathogens remain more or less similar (approx. 20\% to the total) in carrot and tomato, irrespective of reasonably high occurrence of human opportunistic pathogens (carrot) and plant beneficial bacteria (tomato). However, the occurrence of human pathogens was below 20\% when the combined population of human opportunistic pathogens and plant beneficial bacteria (onion) or plant beneficial and environmentally beneficial bacteria (cucumber) was above $50 \%$. Percentage of human pathogens was less than $20 \%$, only when population of plant beneficial bacteria was above $20 \%$. Population of human opportunistic pathogens was $45,36,17$ and $8 \%$ respectively in onion, carrot, cucumber and tomato compared to the population percentage of 25, 17, 36 and 63 of plant beneficial bacteria in these vegetables. There is a clear evidence for the suppressive effect of plant beneficial bacteria on human opportunistic pathogens in cucumber and tomato. When the population of plant beneficial bacteria was above $17 \%$ (onion - 25 ; cucumber - 36; tomato - 63), the plant pathogens were accordingly suppressed (onion - 5; cucumber - 3; tomato - 0). Although pathogen population was less (5\%) due to higher number of human opportunistic pathogens $(45 \%)$, as observed in onion, similar trend was not observed in cucumber and tomato where the suppression of plant pathogens ( 3 and $0 \%$ respectively) was parallel to human opportunistic pathogens (17 and 8\% respectively). This indicates the suppressed population of these two groups of bacteria are independent of each other and dependent on plant beneficial bacteria. It can be concluded that plant beneficial bacteria suppresses both plant and human opportunistic pathogens. Occurrence of commensal bacteria lacks correlation with population of other categories of bacteria. However, commensal bacteria were found to be suppressed when all other bacteria contribute reasonably to the total population as observed in carrot. Higher occurrence of human opportunistic bacteria ( $45 \%$ in onion) was found to have a significant effect on environmentally beneficial bacteria. Previous reports indicate the difference in composition of plant microbiome based on the soil contamination with pollutants as well as organic cultivation and pesticide usage $[60,61]$. Hence, the observed composition of the vegetable bacteriome would be due to the prevailing soil conditions such as pollutant and pesticide level. Further studies on the bacteriome of these vegetables from different agro-climatic zones, soils and cultivation conditions would be useful in understanding the basal level bacterial species specific to these vegetables. In addition, such studies will also help to identify soil, climatic zone and pollutant specific species which have gained endophytic status.

\section{Conclusions}

The complex microbial community analysis and their interactions with plant have greater potential to elucidate interactions between host plants and bacteria as well as bacteria-bacteria interactions. Elucidating the cross-talk between different bacterial communities would not only help in understanding the interaction but also to evolve new biocontrol agents for plant and human pathogens. Based on the observations on relative population density of different categories of the bacteriome in salad vegetables, we propose that there is a greater potential to study the native endophytic plant beneficial bacteria and to develop them as biocontrol agents against not only the plant pathogens, but also the human pathogens that are harboured by plants.

\section{Additional file}

Additional file 1: Table S1. (a). Morphological and biochemical characterization of bacterial isolates from carrot. (b). Morphological and biochemical characterization of bacterial isolates from cucumber. (c). Morphological and biochemical characterization of bacterial isolates from onion. (d). Morphological and biochemical characterization of bacterial isolates from tomato. (DOC $233 \mathrm{~kb}$ )

\section{Abbreviations \\ AIA: Aeromonas Isolation Agar; BLAST: Basic Local Alignment Search Tool; C: Citrate; CA: Certemaid Agar; CDC: Center for Disease Control and Prevention; CFU: Colony Forming Units; CNS: Central Nervous System; CSPI: Center for Science in the Public Interest; EMBA: Eosin Methylene Blue Agar; FDA: US Food and Drug Administration; I: Indole; M: Motility; MR: Methyl Red; MSA: Mannitol Salt Agar; N: Nitrate; O: Oxidase; ONB: O- nitrobenzoate; PAMP: Pathogen Associated Molecular Patterns; PHB: P- hydroxybenzoate; PTI: PAMP- triggered immunity; SSA: Salmonella_-Shigella Agar; T3SS: Type III Secretion System; TAL: Transcription Activator Like effector; VP: Voges_-Proskauer; WHO: World Health Organization}

\section{Acknowledgement}

We acknowledge the management of VIT University, Vellore, India for providing the facilities, laboratory space and support in carrying out the work

\section{Funding}

This research did not receive any specific grant from funding agencies in the public, commercial, or not-for-profit sectors. 


\section{Availability of data and material}

The datasets generated and/or analysed during the current study are available in the GenBank repository, https://www.ncbi.nlm.nih.gov/nuccore/ ?term=nithya+and+Babu+VIT+University.

\section{Authors' contributions}

AN: Performed the sampling, microbiological work, amplification and also contributed in manuscript writing. SB: Conceived the concept, mentored the work, contributed in sequence analysis and submission to GenBank and contributed in manuscript writing. Both authors read and approved the final manuscript.

\section{Competing interests}

The authors declare that they have no competing interests.

\section{Consent for publication}

Not applicable.

\section{Ethics approval and consent to participate} Not applicable.

\section{Publisher's Note}

Springer Nature remains neutral with regard to jurisdictional claims in published maps and institutional affiliations.

\section{Received: 9 January 2017 Accepted: 7 March 2017}

Published online: 14 March 2017

\section{References}

1. Tayo BC, Odu NN, Esen CU, Okonko IO. Microorganisms associated with spoilage of stored vegetables in Uyo Metropolis, Akwa Ibom state, Nigeria. Nat Sci. 2012;10:23-32

2. Vaz BM, Fink RC, Gonzalez FD, Sadowsky MJ. Minireview enteric pathogenplant interactions: molecular connections leading to colonization and growth and implications for food safety. Microbes Environ. 2014;29:123-35.

3. Leff JW, Fierer N. Bacterial communities associated with the surfaces of fresh fruits and vegetables. PLoS One. 2013;8:1-9.

4. Rovira J, Cencic A, Santos E, Jakobsen M. Biological hazards. In: Luning PA Devlieghere F, Verhe R, editors. Safet in the agri-food chain. The Netherlands: Wageningen Academic Publishers; 2006.

5. Wiedemann A, Payant IV, Chausse AM, Schikora A, Velge P. Interactions of Salmonella with animals and plants. Front Microbiol. 2015;5:1-18.

6. Saitou N, Nei M. The neighbor-joining method: A new method for reconstructing phylogenetic trees. Mol Biol Evol. 1987;4:406-25.

7. Tamura K, Stecher G, Peterson D, Filipski A, Kumar S. MEGA6: molecular evolutionary genetics analysis version 6.0. Mol Biol Evol. 2013;30:2725-9.

8. Hammer O, Harper DAT, Rayn PD. PAST: Paleontological statistics softer pakage for education and data analysis. Palaeontol Electronic. 2001;4:1-9.

9. Jackson CR, Randolph KC, Osborn LO, Tyler HL. Culture dependent and independent analysis of bacterial communities associated with commercial salad leaf vegetables. BMC Microbiol. 2013;13:1-12.

10. Berg G, Erlacher A, Smalla K, Krause R. Vegetables microbiomes is there a connection among opportunistic infections, human health and our gut feeling? Microb Biotechnol. 2014;7:487-95.

11. Rivas M, Chines I, Miliwebsky E, Masana M. Risk factors for Shiga toxin producing Escherichia coli associated human diseases. Microbiol Spectrum. 2014;2:1-14

12. Felicio MIDS, Hald T, Liebana E, Allende A, Hugas M, The CN, Johannersen GK, Niskanen T, Uyttendaele M, Mchauchlin J. Risk ranking pathogens in ready-to-eat unprocessed foods of non - animal origin (FONAO) in the $\mathrm{EV}$ : Initial evaluation using outbreak data (2007-2011). Int J Food Microbiol. 2015:195:9-19.

13. Teplitski M, Barak JD, Schneider KR. Human enteric pathogens in produce :un-answered ecological questions with direct implications for food safety. Curr Opin Biotechnol. 2009:20:166-71.

14. Viswanathan P, Kaur R. Prevalence and growth of pathogens on salad vegetables, fruits and sprouts. Int J Hyg Environ Health. 2001;203:205-13.

15. Overbeek LSV, Doom JV, Wichers JH, Amerongen AV, Roermund HJWV, Willemsen PTJ. The arable ecosystem as bottle ground for emergence of new human pathogens. Front Microbiol. 2014;5:1-17.
16. Cortes JFC, Monter NL, Cueto ALC, Rangel LPS, Reptto ACH, Hernandez DL, Gutierrez SR, Rendon EF, Merchand JAG. Microbiological Quality of ready-toeat vegetables collected in Mexico city: Occurrence of aerobic-mesophilic bacteria, fecal coliforms and potentially pathogenic nontuberculous Mycobacteria. BioMed Res Int. 2015;2015:789508.

17. Phukon M, Sahu P, Srinath R, Nithya A, Babu S. Unusual occurance of Staphylococcus warneri as endophyte in fresh fruits along with usual Bacillus spp. J Food Safety. 2013;33:102-6.

18. Shivaji S, Chaturvedi P, Begum Z, Pindi PK, Manorama R, Padmanaban A, Shouche YS, Pawar S, Vaishampayan P, Dutt CBS, Datta GN, Manchanda RK, Rao UR, Bhargava PM, Narlikar JV. Janibacter hoylei sp. nov., Bacillus isronensis sp. nov. and Bacillus aryabhattai sp. nov., isolated from cryotubes used for collecting air from the upper atmosphere. Int J Syst Evol Microbiol. 2009;59:2977-86.

19. An SY, Asahara M, Goto K, Kasai H, Yokota A. Terribacillus saccharophilus gen nov., sp. Nov. and Terribacillus halophilus sp. nov., spore-forming bacteria isolated from field soil in Japan. Int J Syst Evol Microbiol. 2007:57:51-5.

20. Gatson JW, Benz BF, Chandrasekaran C, Satomi M, Venkateswaran K, Hart ME. Bacillus tequilensis sp. nov., isolated from a 2000-year-old Mexican shafttomb, is closely related to Bacillus subtilis. Int J Syst Evol Microbiol. 2006;56:1475-84

21. Raymond B, Wyres KL, Sheppard SK, Ellis RJ, Bonsall MB. Environmental factors determining the epidemiology and population genetic structure of Bacillus cereus group in the field. PLoS Pathog. 2010;6:1-13.

22. Ganz HH, Turner WC, Brodie EL, Kusters M, Shi Y, Sibanda H, Torok T, Getz WM. Interactions between Bacillus anthracis and plants may promote anthrax transmission. PLoS Negl Trop Dis. 2014;8:2903.

23. Smerilli M, Neureiter M, Wurz S, Haas C, Fruhauf S, Fuchs W. Direct fermentation of potato starch and potato residues to lactic acid by Geobacillus stearothermophilus under non-sterile conditions. J Chem Technol Biotechnol. 2015;90:648-57.

24. Jung WJ, Jin YL, Park RD, Kim KY, Lim KT, Kim TM. Treatment of Paenibacillus illinoisensis suppresses the activities of antioxidative enzyme in pepper roots caused by Phytophthora capsici infection. World J Microbiol Biotechnol. 2006;22:901-7.

25. Chaves-Moreno D, Wos-Oxley ML, Jauregui R, Medina E, Oxley APA, Pieper $\mathrm{DH}$. Exploring the transcriptome of Staphylococcus aureus in its natural niche. Sci Rep. 2016; 6. doi: 10.1038/srep33174.

26. Dakic I, Morrison D, Vukovic D, Savic B, Shittu A, Jezek P, Hauschild, Stepanovic S. Isolation and molecular characterization of Staphylococcus sciuri in the hospital environment. J Clin Microbiol. 2005:43:2782-5.

27. Buttner $H$, Mack D, Rohde H. Structural basis of Staphylococcus epidermidis biofilm formation: mechanisms and molecular interactions. Front Cell Infect Microbiol. 2015;5:1-15

28. Barros EM, Ceotto H, Bastos MCF, Santos KRN, Giambiagi M. Staphylococcus haemolyticus as an important hospital pathogen and carrier of methicillin resistance genes. J Clin Microbiol. 2011;50:166-8.

29. Tibra NK, Jalali S, Reddy AK, Narayanan R, Agarwal R. Traumatic endophthalmitis caused by Staphylococcus gallinarum. J Med Microbiol. 2010;59:365-6.

30. Santoro MV, Bogino PC, Nocelli N, Cappellari LR, Giordano WF, Banchio E. Analysis of plant growth-promoting effects of fluorescent Pseudomonas strains isolated from Mentha piperita rhizosphere and effects of their volatile organic compounds on essential oil composition. Front Microbiol. 2016. http://dx.doi.org/10.3389/fmicb.2016.01085.

31. Wong V, Levi K, Baddal B, Turton J, Boswell TC. Spread of Pseudomonas fluorescens due to contaminated drinking water in a bone marrow transplant unit. J Clin Microbiol. 2011:49:2093-6.

32. Hu YH, Dang W, Sun L. The ton B- dependent outer membrane receptor of Pseudomonas fluorescens: virulence and vaccine potential. Arch Microbiol. 2012;194:795-802

33. Miron D, Keness $Y$, Bor $N$, Spiegel $R$, Horowitz $Y$. Pseudomonads stutzeri knee arthritis in a child: case report and review. J Pediatr Orthop B. 2007;16:419-21

34. Romanenko LA, Uchino M, Falsen E, Lysenko AM, Zhukova NV, Mikhailov W. Pseudomonas xanthomarine sp. a novel bacterium isolated from marine ascidian. J Gen Appl Microbiol. 2005;51:65-71.

35. Koechler S, Ploetze FA, Armanet CB, Chollet FG, Salmeron AH, Jost B, Lievremont D, Philipps M, Plewniak F, Bertin PN, Lett MC. Constituvative arsenite oxidase expression detected in arsenic-hypertolerant Pseudomonas xanthomarine S11. Res Microbiol. 2015;166:205-14 
36. Sheshtawy HSE, Khalil NM, Ahmed W, Abdallah RI. Monitoring of oil pollution at Gemsa Bay and bioremediation capacity of bacterial isolates with bio-surfactants and nanoparticles. Marine Poll Bull. 2014;87:191-200.

37. Manickam N, Ghosh A, Jain RK, Mayilraj S. Description of a novel indoleoxidizing bacteria Pseudomonas indoloxydans sp. nov., isolated from pesticide-contaminated site. Syst Appl Microbiol. 2008;31:101-7.

38. Morohoshi T, Wang WZ, Someya N, Ikeda T. Genome sequence of Microbacterium testaceu StLB037, an N-Acylhomoserine Lactone-Degrading bacterium isolated from potato leaves. J Bacteriol. 2011;193:2072-3.

39. Chulze SN, Palazzini JM, Torres AM, Barros G, Ponsone ML, Geisen R, Schmidt HM, Kohl J. Biological control as a strategy to reduce the impact of mycotoxins in peanut, grapes and cereals in Argentina. Food Addit Contam Part A. 2015;32:471-9.

40. Checa CM, Chaparro LC, Ruiz JP, Monje AP, Alexander JLR, Salvatierra J, Raya E. Septic arthritis due to Cellulosimicrobium cellulans. J Clin Microbiol. 2011;49:4391-3

41. Yu GH, Xiey H, Chen YH, Chen YF, Cheng P. Mitigating the repress of cinnamic acid to cucumber growth by microbial strain. Wei Sheng Wu Xue Bao. 2006;46:934-8.

42. Islam S, Akanda AK, Prova A, Islam MT, Hossaim MM. Isolation and identification of plant growth promoting rhizobacteria from cucumber rhizosphere and their effect on plant growth promotion and disease suppression. Front Microbiol. 2016;6:1-12.

43. Garcia AV, Charrier A, Schilcora A, Bigeard J, Pateyron S, Moreau MLT, Evrard A, Mithofer A, Magniette MLM, Payant IV, Hirt H. Salmonella enteric flagellin is recognized via FLS2 and activities PAMP-triggered immunity in Arabidopsis thaliana. Mol Plant. 2014;7:657-74.

44. Penteado AL, Leitao MFF. Growth of Salmonella Enteritidis in melon, water melon and papaya pulp stored at different time and temperature. Food Control. 2004:15:363-73.

45. Marvasi M, Hochmuth GJ, Giurcanu MC, George AS, Noel JT, Bartz J, Teplitski M. Factors that affect proliferation of Salmonella in tomatoes post-harvest: the roles of seasonal effects, irrigation regime, crop and pathogen genotype. PLoS One. 2013:8:1-11.

46. Guo X, Chen J, Brackett RE, Beuchat LR. Survival of Salmonellae on and in tomato plants from the time of inoculation at flowering and early stages of fruit development through fruit ripening. Appl Environ Microbiol. 2001:67:4760-4

47. Montero D, Bodero M, Riveros G, Lapierre L, Gaggero A, Vidal RM, Vidal M. Molecular epidemiology and genetic diversity of Listeria monocytogenes isolated from wide variety of ready-to-eat foods and their relationship to clinical strains from listeriosis outbreaks in Chile. Front Microbiol. 2015;6:1-8.

48. Keynan $\mathrm{Y}$, Weber $\mathrm{G}$, Sprecher $\mathrm{H}$. Molecular identification of Exiguobacterium acetylicum as the aetiological agent of bacteraemia. J Med Microbiol. 2007;56:563-4.

49. Selvakumar G, Joshi P, Nazim S, Mihra PK, Kundu S, Gupta HS. Exigubacterium acetylicum train 1P (MTCC 8707) a novel bacterial antagonist from the North Western Indian Himalayas. World J Microbiol Biotechnol. 2009:25:131-7.

50. Yacoub AT, Katayama M, Tran J, Zadikany R, Kandula M, Greene J. Bordetella bronchiseptica in the immunosuppressed population - A case series and review. Mediterr J Hematol Infect Dis. 2014;6:1-7.

51. Sharma NK, Pandey J, Gupta N, Jain RK. Growth and physiological response of Arthrobacter protophormiae RKJ100 toward higher concentrations of onitrobenzoate and p-hydroxybenzoate. FEMS Microbiol Lett. 2007;271:65-70.

52. Imirzalioglu C, Hain T, Hossain H, Chakraborty T, Domann E. Erythema caused by localised skin infection with Arthrobacter mysorens. BMC Infect Dis. 2010;10:1-4

53. Duggan JM, Goldstein SJ, Chenoweth CE, Kauffman CA, Bradley SF. Achromobacter xylosoxidans bacteremia: report of four cases and review of the literature. Clin Infect Dis. 1996;23:569-76.

54. Townsend SM, Hurrell E, Barron JC, Carrillo CL, Forsythe SJ. Characterization of an extended-spectrum beta-lactamase Enterobacter hormaechei nosocomial outbreak, and other Enterobacter hormaechei misidentified as Cronobacter (Enterobacter) sakazakii. Microbiology. 2008;154:3659-67.

55. Davin-Regli A, Pages JM. Enterobacter aerogenes and Enterobacter cloacae; versatile bacterial pathogens confronting antibiotic treatment. Front Microbiol. 2015:6:1-10

56. Lau YY, Yin WF, Chan KG. Enterobacter asburiae strain L1: Complete genome and whole genome optical mapping analysis of a quorum sensing bacterium. Sensors. 2014;14:13913-24
57. Broughton WJ, Hern G, Blair M, Beebe S, Gepts P, Vanderleyden J. Beans (Phaseolus spp.) - model food legumes. Plant Soil. 2003:252:55-128.

58. Lee JH, Shin H, Park HJ, Ryu S, Han SW. Draft genome sequence of Xanthomonas axonopodis pv. Glycines 8ra possessing transcription activator - like affectos used genetic engineering. J Biotechnol. 2014;179:15-6.

59. Surette MA, Sturz AV, Lada RR, Nowak J. Bacterial endophytes in processing carrots (Daucus carota L. var. sativus): their localization, population density, biodiversity and their effects on plant growth. Plant Soil. 2003;253:281-390.

60. Xia Y, DeBolt S, Dreyer J, Scott D, Williams MA. Characterization of culturable bacterial endophytes and their capacity to promote plant growth from plants grown using organic or conventional practices. Front Plant Sci. 2015;6:490.

61. Lemactud R, Shen SY, Lau M, Fulthorpe R. Bacterial endophytes isolated from plants in natural oil seep soils with chronic hydrocarbon contamination. Front. Microbiol. 2016; https://doi.org/10. 3389/fmicb.2016.00755.

\section{Submit your next manuscript to BioMed Central and we will help you at every step:}

- We accept pre-submission inquiries

- Our selector tool helps you to find the most relevant journal

- We provide round the clock customer support

- Convenient online submission

- Thorough peer review

- Inclusion in PubMed and all major indexing services

- Maximum visibility for your research

Submit your manuscript at www.biomedcentral.com/submit
) Biomed Central 